This article challenges the widespread notion that civic nationalism is dominant in Western Europe and North America, whereas ethnic nationalism is dominant in Central and Eastern Europe. After laying out the civic-West/ethnic-East argument, it refines the civic/ethnic dichotomy and deduces the state policies that flow from ethnic, cultural, and civic conceptions of national identity. It then employs survey data from 15 countries to measure mass conceptions of national identity by analyzing attitudes on criteria for national membership and state policy toward assimilation and immigration. The article finds that the civic-Westethnic-East stereotype, when true, is only weakly true, and according to several measures is false. Finally, several explanations for strong cultural national identities in the West and strong civic national identities in Eastern Europe are given.

\title{
CHALLENGING THE CIVIC/ETHNIC AND WEST/EAST DICHOTOMIES IN THE STUDY OF NATIONALISM
}

\author{
STEPHEN SHULMAN \\ Southern Illinois University at Carbondale
}

\begin{abstract}
The distinction between civic and ethnic nations is one of the most widely employed conceptual building blocks in the study of ethnic relations and nationalism. A closely related distinction is that between Western and Eastern nations, according to which Western Europe and the United States developed primarily as civic nations and Germany and Eastern Europe primarily as ethnic nations. Unfortunately, few analyses challenge these dichotomies theoretically or empirically. This article sceks to assess the accuracy of the conventional wisdom that fundamentally accepts the civicWest/ethnic-East pattern of national development. Using survey data from 15 countries, it argues that the standard view greatly exaggerates the current differences in national identity hetween the West and East. Western civic nations are more ethnic than is usually recognized, and Eastern ethnic nations
\end{abstract}

AUTHOR'S NOTE: I would like to thank Taras Kuzio for his comments on an earlier version of this article.

COMPARATIVE POLITICAL STUDIES, VI. 35 No. 5, June 2002 554-585

(1) 2002 Sage Publications 
are more civic. Furthermore, on some measurements, countries in Central and Eastern Europe are more civic and less ethnic than Western countries.

\section{THE CIVIC/ETHNIC AND WEST/EAST CONCEPTUAL DICHOTOMIES}

For much of the 20th century, scholars of nations and nationalism have commonly argued that (a) there are many different traits that can provide the foundation for national unity and identity, and (b) nations differ in the mix of the traits that form the basis of their unity and identity. A simple classificatory scheme has arisen that distinguishes nations as civic, political, or territorial on one hand, versus ethnic or cultural on the other. Parallel with this conceptual distinction is a geographic one in which civic components of nationhood are dominant in Western Europe and the United States, whereas ethnic components are dominant in Central and Eastern Europe.

In his 1907 work Cosmopolitanism and the National State, German historian Friedrich Meincke (1970) became one of the first scholars to assert a fundamental difference between political and cultural nations. However, it was Czech émigré Hans Kohn who developed and popularized the dichotomous framework in his 1944 book The Idea of Nationalism and later works (Kohn, 1944, 1946, 1949). Kohn argued that in the West, particularly England, France, the Netherlands, Switzerland, and the United States, nationalism was primarily political. There, ideas of the nation and nationalism arose within preexisting state structures that encompassed populations with a relatively high degree of cultural homogeneity, or developed simultaneously with those structures. Inspired by Enlightenment ideas of liberty and equality, Western nationalism struggled against dynastic rule and equated citizenship with membership in the nation. Members of the nation were unified by their equal political status and their will as individuals to be part of the nation. Thus in the Western model, the state temporally precedes (or coincides with) the development of the nation. In the socially and politically more backward areas of Central and Eastern Europe and Asia, however, nationalism arose in polities that very ponrly coincided with cultural or ethnic boundaries (e.g., Russian, Austro-Hungarian, and Ottoman empires). In these regions, Kohn (1944) argues, nationalism struggled "to redraw the political boundaries in conformity with ethnographic demands" (p. 329). Thus in the Eastern model the nation precedes, and seeks to create, the state. Nations in the East consolidated around the common heritage of a people and the irrational idea of the volk (people), instead of around the notion of citizenship. 
Many contemporary scholars employ the analytical distinction between civic/political and ethnic/cultural nations originated by Meincke and Kohn, although they differ in their precise characterization of these concepts. Alter (1994) contrasts cultural nations, based on common heritage, language, distinct area of settlement, religion, customs, and history, with political nations, composed of politically aware citizens equal before the law (p. 9). In Smith's (1991) Western or civic model, national unity arises from a historic territory, laws and institutions, the legal-political equality of members that expresses itself in a set of rights and duties, and a common civic culture and ideology. Smith's non-Western ethnic nation is based on descent or presumed descent, and thus is seen by its members as a "fictive super-family." In addition, vernacular culture, especially language and customs, is a key element of the ethnic nation (p. 12).

Ignatieff (1993) characterizes the civic nation as a "community of equal, rights-bearing citizens, united in patriotic attachment to a shared set of political practices and values" (pp. 6-7,9). In contrast to this notion, which originated in Great Britain, France, and the United States, Ignatieff explains that for the German Romantics of the 19th century, national unity sprung not from "the cold contrivance of shared rights but [from] the people's preexisting ethnic characteristics: their language, religion, customs, and traditions" (pp. 6-7). In addition, he asserts that ethnic nationalism tells people to "only trust those of your own blood" (p. 9).

Regardless of the differences in definition, the assertion that Western Europe and the United States developed primarily as civic nations and Eastern Europe primarily as ethnic nations is common. But it is not just a historical argument; many scholars see the continuation of historical patterns in current national identities in the West and East. Particularly with the collapse of communism in the Soviet Union and Eastern Europe, the conceptualization has become a standard point of departure for many studies of ethnic relations and nationalism in the post-communist "New Europe." According to Brubaker (1996), the 20 or so new post-communist states of Eastern Europe and the former Soviet Union were "conceived and justified, in the nationalist movements preceding their independent statehood as well as after statehood was achieved, as the state of and for a particular ethnonational group" (p. 65, note 13). Brubaker thinks that civic notions of nationhood have little chance of prevailing in the new states of Eurasia, given the "pervasively institutionalized understandings of nationality as fundamentally ethnocultural rather than political, as sharply distinct from citizenship, and as grounding claims to ownership of polities" (p. 105).

Another expert on Eastern Europe, George Schopflin (1996), also stresses "the strongly ethnic character of nationhood and state legitimation" in the 
region (p. 153). Following Kohn, Schopflin argues that in the Wcst citizenship arose before or concomitant with nationalism, whereas in Eastern Europe elites mobilized nations around ethnicity in an attempt to carve states from the empires that subjugated them. But in addition to this relatively distant historical source of current ethnic nationalism in Eastern Europe, Schopflin underscores the role that communist rule played.

Schopflin links communism and ethnic nationalism in the region in several ways. First, because communism was associated with foreign oppression, opposition to communist rule became a national project. "In these circumstances," Schopflin (1996) writes, "it was very difficult for any civic dimension of nationhood to emerge" (p. 153). Second, communism destroyed civil society in the region, turning communities there into "civic deserts" characterized by mistrust and atomization. Consequently, ethnonational identities were the only ones in the public sphere that could become salient (p. 153). Finally, communism pushed out other competing ideas and values, making it "much easier for an undiluted nationalism referring solely to ethnicity to survive more or less intact" (Schopflin, 1995, p. 53). As a result, many national disputes from the pre-communist era were swept under the carpet, only to reemerge with the end of communism.

A final argument for the alleged predominance of cthnic nationalism in Eastern Europe concerns the newness of the states and regimes that are constructing from scratch democratic political and legal institutions. Echoing Gellner (1992), Snyder (1993) contends that ethnic nationalism fills an institutional vacuum. Thus "ethnic nationalism is the default option: It predominates when institutions collapse, when existing institutions are not fulfilling people's basic needs, and when satisfactory alternative structures are not readily available" (p. 86). In the context of wholesale institutional transformation in Eastern Europe, with its attendant economic malaise, widespread corruption, and high crime rates, one would expect ethnically based conceptions of nationhood to be very strong in the region according to this argument.

\section{CRITIQUE OF THE CIVIC/ETHNIC AND WEST/EAST DICHOTOMIES}

The civic/ethnic and West/East dichotomies have been criticized, although not to the extert one would expect given their simplicity and ubiquity. The criticisms that exist can be categorized as normative, conceptual, and empirical.

Several scholars criticize the dichotomies for their normative, ethnocentric bias. For example, Yack (1999) writes that "the civic/ethnic dichot- 
orily parallels a series of other contrasts that should set off alarm bclls: not only Western/Eastern, but rational/emotive, voluntary/inherited, good/bad, ours/theirs!" (p. 105). And McCrone (1998) comments that the civic/ethnic distinction "does lend itself to ethnocentric caricature-why can't they be more like $u s$ ?" (p. 9).

Conceptually, some scholars have attacked the logic of the civic/ethnic distinction. Yack challenges the notion that a civic identity must be freely and rationally chosen, whereas an ethnic identity is inherited and emotionally based. Civic identities can be inherited too, Yack (1999) argues (p. 109). Furthermore, both Nielsen and Kymlicka note that it is a mistake to equate ethnic with cultural nationalism, because they differ according to their openness to outsiders. Each scholar points to Quebec and Flanders as nationalisms that have been labeled ethnic but in actuality are cultural (Kymlicka, 1999, p. 133; Nielsen, 1999, p. 126). Nieguth (1999) similarly calls for unpacking the dichotomy, seeing ancestry, race, culture, and territory as analytically distinct bases for national membership.

On the empirical side, most scholars who employ the civic/ethnic and West/East dichotomies are quick to say that most states and nations contain both ethnic and civic components. Smith (1991), for example, writes that "every nationalism contains civic and ethnic clements in varying degrees and different forms. Sometimes civic and territorial elements predominate; at other times it is the ethnic and vernacular components that are emphasized" (p. 13). Still, Smith contends that the civic/ethnic distinction "remains valid and useful" (p. 81). Calhoun (1997) writes that although France and Germany are commonly seen as typical civic and ethnic nations, respectively, "France and Germany, and all of Western and Eastern Europe, have been shaped by the international discourse of nationalism-including both ethnic claims and civil projects of popular political participation" (p. 89).

Despite such empirical criticisms, there have been no works that have attempted to systematically measure and compare conceptualizations of nationhood in Western Europe/North America and Central/Eastern Europe. To empirically evaluate the civic-West/ethnic-East characterization, it is necessary to refine the civic/ethnic dichotomy and settle on a strategy for measuring national identity.

The main problem with the civic/ethnic dichotomy is that it collapses too much in the ethnic category. As Kymlicka, Nielsen, and Nieguth correctly point out, ethnic and cultural components of identity should be distinguished. Superior to the current dichotomy is a scheme with three variants of what can be called the content of national identity - factors that people in a nation believe are, or should be, the most important in uniting and distinguishing them from others and that become the basis for defining membership in the 
Table 1

Alternative Contents of National Identity

\begin{tabular}{ll}
\hline Content of National Identity & Key Components \\
\hline Civic & territory \\
& citizenship \\
& will and consent \\
& political ideology \\
& political institutions and rights \\
Cultural & religion \\
& language \\
Ethnic & traditions \\
& ancestry \\
\hline
\end{tabular}

nation. The main variants for the content of national identity are civic, cultural, and ethnic (see Table 1). The existing literature on civic nations produces five main components of the civic identity, according to which national unity and membership in the nation derive from attachment to a common territory, citizenship, helief in the same political principles or ideology, respect for political institutions and enjoyment of equal political rights, and will to be a part of the nation. Cultural identity is based on nonpolitical cultural traits. The key components here are language, religion, and traditions. Finally, for ethnic national identity, shared ancestry and race are the dominant criteria by which membership in the nation is defined.

To some extent, the three variants of national identity differ in their level of inclusiveness. It is very difficult for "outsiders" to meet the ethnic criteria because one cannot choose or change one's genes or ancestors. But it is possible to adopt cultural traits and thereby enter the nation. Some of the civic criteria are indeed relatively easy to meet, such as will and consent, but citizenship depends on the choice not of the prospective member of the nation but of the state. In addition, as will be discussed in more detail below, attachment to territory can be an exclusive characteristic that is hard or impossible for outsiders to acquire.

Beside refining the civic/ethnic framework, evaluating the civic-West/ ethnic-East argument requires measuring and distinguishing types of nationhood. Two main options exist: examining the policies of states or the attitudes of members of the nation. Scholars often interpret a state's policies as supportive of the construction of ethnic versus civic nations, and to some extent belief in the civic-West/ethnic-East pattern is based on analysis of these policies (see, for example, Brubaker, 1992). 
The problem with inferring national identity from state policies concerning such issues as citizenship, cultural assimilation, treatment of minorities, and immigration is that to the extent that such policies reflect conceptions of identity, they embody the views of a very narrow segment of the state's population: the political elite in power at the time the policies were enacted. With a change in ruling parties or coalitions, policies can change rapidly. A superior analysis would be one investigating the national identity of either the entire spectrum of political elites in a country or its mass population. This study chooses the latter.

Another problem is that state policies may reflect concerns other than national identity. This is especially the case with immigration policy, which may also be influenced by concerns over the economic and social impact of immigration. Nevertheless, mass attitudes toward state policies can be useful as an indirect measure of the content of national identity that people support in a country. Thus, in addition to directly analyzing mass attitudes on national membership criteria, this article explores mass policy preferences on cultural assimilation and immigration.

To do so, however, we must deduce the policies that follow from civic, cultural, and ethnic ideas of nationhood. Again, the lack of inquiry into this mattcr is puzzling. Extant discussions of the relationship between national identity and state policies are mired in confusion. The primary problem is that many scholars conflate civic nationhood with cultural assimilation policies. For example, Brubaker (1992) argues that a policy of cultural assimilation "presupposes a political conception of membership" in the nation (p. 8). In a similar vein, Kymlicka (1999) describes how ethnic conflicts often result from the attempt by civic nationalists to forcibly incorporate and assimilate ethnic minorities into the dominant culture (p. 134).

The weakness of such claims is that no theoretical or logical link is made between civic nationalism and cultural assimilation of minorities. These scholars simply label France and other Western nations civic, recognize that they engaged in assimilation, and therefore conclude that civic nationhood demands or leads to assimilation. But a truly civic conception of the nation entails no need for cultural unity. People in a purely civic nation are united by such traits as common citizenship, respect for law and state institutions, belief in a set of political principles, and so forth. Similarily in language, religion, and other cultural markers is not necessary for the development of such traits.

Theoretically, the idea of civic nationhood leads to one of two policies in the cultural sphere (see Table 2). The first option is a laissez-faire approach in which the state is as culturally neutral as possible and promotes individual, not collective, rights. A second option is a policy of multiculturalism. Here 
Table 2

National Identity and Key Policy Issues

\begin{tabular}{lcc}
\hline Content of National Identity & Cultural Policy & Immigration Policy \\
\hline Civic & $\begin{array}{c}\text { Promote no ethnic cultures } \\
\text { or promote minority } \\
\text { ethnic cultures } \\
\text { Do not encourage assimilation }\end{array}$ & Open immigration \\
Cultural & $\begin{array}{c}\text { Promote dominant ethnic } \\
\text { group's culture } \\
\text { Encourage assimilation }\end{array}$ & Conditional immigration \\
& $\begin{array}{c}\text { Preference for culturally } \\
\text { similar immigrants }\end{array}$ \\
& group's culture & Restrictive immigration \\
& Do not encourage assimilation & $\begin{array}{c}\text { Preference for ethnically } \\
\text { similar immigrants }\end{array}$ \\
\hline
\end{tabular}

the state recognizes collective rights and promotes the maintenance or development of minority cultures in an attempt to buy ethnic minority attachment to the state and its institutions and territory. Such an attempt is predicated on the (civic) assumption that will and consent are central aspects of national identity. In contrast, nation building under a cultural concept of nationhood requires that the state pursue cultural assimilation of minorities, because cultural unity is the foundation for a strong nation-state in this formulation. Here the state will actively promote the majority ethnic group's history and culture in education and language policies as the core around which to build a national culture. Finally, an ethnic conception of the nation also logically leads to the promotion of the dominant ethnic group's culture, because the state is conceived here as the state of and for a particular group, and a group's common ethnic identity is expressed through its culture. But assimilation is not encouraged because even if other ethnic groups acquire the majority group's culturc, they can never be part of the latter group, and the ethnic nation would not be strengthened or expanded in any meaningful way by such assimilation.

In the realm of immigration, a civic nation should be relatively open to foreigners of any background. The civic nation has a large capacity to absorb new members because it makes few demands on the nonpolitical beliefs and characteristics of its population. For those immigrants who live in the country long enough, or their offspring, it is relatively easy to meet the criteria for national membership. A purely cultural nation should also admit immigrants, 
but only conditionally. Adopting a ncw culture is not easy and is sometimes resisted. Therefore immigration should proceed only as long as immigrants and their offspring are willing and able to assimilate into the dominant culture. Furthermore, a cultural nation will have a bias in accepting immigrants from culturally similar countries, precisely because this will facilitate their assimilation into the national culture. Finally, ethnic nationhood calls for a highly restrictive immigration policy. Immigrants cannot be true members of the nation because they lack the "proper" ancestry. Therefore any ethnic nation that permits large numbers of immigrants decreases the numerical dominance of the majority ethnic group and risks fueling discord and disharmony. The exception here is immigrants who are of the same ethnic stock as the dominant group in the ethnic nation. The state should permit easy entry to such immigrants.

\section{ASSESSING THE CIVIC-WEST/ ETHNIC-EAST STEREOTYPE}

To evaluate the accuracy of the image of a civic West and an ethnic East, this article uses a large multicountry public opinion dataset. Under the auspices of the International Social Survey Program (ISSP), in 1995-1996, 23 countries implemented a survey with questions related to national identity. Fifteen countries were selected for analysis here. Representing the West are the United States, Canada, Great Britain, Spain, the Netherlands, Norway, and Sweden. In Central Europe, Germany was selected and divided into its Western and Eastern components. Analyzing the two parts of Germany separately is necessary, given their disparate postwar histories, and permits a rough assessment of the effect of communism on national identity. Finally, Poland, Hungary, the Czech Republic, Slovakia, Bulgaria, Slovenia, and Latvia were chosen to represent Eastern Europe. ${ }^{1}$ Majority and minority groups in all of these states are likely to differ in their conceptions of national identity. Consequently, it is necessary to focus on one or the other for the purposes of comparative analysis, so that any differences in identity that are found are not the result of the proportion of minorities in the various countries. This study will investigate the views of the majority ethnic or ethnocultural groups. ${ }^{2}$

1. The other European countries participating in the International Social Survey Program study but not included in this analysis were Ireland, Italy, Austria, and Russia.

2. Identifying members of the majority ethnic or ethnocultural group in each country was generally not problematic, because most surveys explicitly asked about ethnicity. The excep- 
Current conceptions of the civic-West/ethnic-East stereotype lead to the prediction that civic national identities should be strongest in the West and weakest in Eastern Europe, with Central Europe - the two halves of Germanyfalling somewhere in between. Similarly, ethnic and cultural national identities should be strongest in Eastern Europe and weakest in the West, with Central Europe again in the middle. Germany should, on the whole, be less ethnically/culturally nationalistic and more civic than Eastern Europe not only because its Western part did not experience communism, which is alleged to increase ethnic nationalism, but also due to the greater political institutional strength and economic prosperity of Germany (its Eastern part included) than Eastern Europe. In addition, Western and Eastern European national identities should not just differ, but differ greatly given the disparate historical contexts (both recent and distant) that are alleged to influence national development. Finally, arguments on the influence of communism on national identity lead to the prediction that Western Germany should be substantially more civic and less ethnic/cultural than Eastern Germany.

\section{DIRECT MEASURES OF NATIONAL IDENTITY ${ }^{3}$}

The ISSP questionnaire contains a battery of questions explicitly designed to measure respondents' conceptualization of national identity and membership. Unfortunately, these questions tap into only the civic and cultural bases of national identity and exclude purely ethnically grounded notions of national identity. Thus this article cannot offer a full test of the civicWest/ethnic-East dichotomy.

Respondents in each country were asked, "Some people say the following things are important for being [e.g., truly British, Spanish, Hungarian, etc.] ${ }^{4}$

tions were the United States, Britain, Spain, and Canada. In the United States, Whites were identified as those who said their ancestors came from any European country, Canada, Australia, or New Zealand. In Britain, the majority group could be identified only by first selecting those who declared themselves to be English, Scottish, Welsh, or British. From this group were selected those living in England. Finally. Spaniards and Canadians who speak Spanish and English. respectively, at home were coded as the majority group.

3. For all calculations in this article, the survey data were weighted using the weighting variable in the dataset.

4. Two exceptions to the phraseology "being truly X" or "being a real X" must be noted. In Slovakia, respondents were asked about the importance of various factors for being "a real citjzen of the Slovakian Republic." In Latvia, the phrase "a teal inhabitant of Latvia" was used. Such wording does bias the question in favor of civic national identification for these two cases. However, this is offset by a sinilar bias in three of the seven Western countries. In Britain, Canada, and the United States, the survey question asks about membership in a group delineated by state territorial boundaries (British, Canadian. American). In contrast, in five of the seven Eastern 
Others say they are not important. How important do you think cach of the following is ... ?" Respondents were asked to rank the following traits for national membership as 1 (very important), 2 (fairly important), 3 (not very important), or 4 (not important at all):

- To have been born in [respondent's country].

- To have citizenship in [respondent's country].

- To have lived in [respondent's country] for most of one's life.

- To be able to speak [the dominant language in respondent's country]. ${ }^{5}$

- To be a [believer in the dominant religion/denomination of respondent's country (e.g., Protestant, Christian, etc.)].

- To respect political institutions and laws of [respondent's country].

- To feel [British, Spanish, Hungarian, etc.].

Of the seven items, those on religion and language evaluate support for cultural national identity, whereas the rest tap into support for civic identity. Four of the five major components of civic identity can be measured with these latter items-will and consent, citizenship, political institutions, and territory. Unfortunately the surveys did not ask a question designed to evaluate the role of political ideology in creating national identity. A question from a separate battery of questions permits measurement of the third major component of cultural identity - traditions. Starting with the civic items, we compare the average scores in each country and in each region (the West, Eastern Europe, and Central Europe) to evaluate the accuracy of the civic-West/ ethnic-East argument.

The question on citizenship asks about the importance of state-sanctioned membership in the civic nation. Those respondents supporting a basically cultural or ethnic notion of national identity should find such official designation of little importance to national membership. The data show that for all countries, most ethnic-majority respondents find citizenship an important component of national identity, as the average scores vary between 1.37 and 1.87 (see Table 3 ). ${ }^{6}$ Note that a country's score must exceed 2.5 in order for its respondents to find, overall, that the given item is unimportant for national membership. Within the relatively narrow range of variation among coun-

European cases and Germany, the survey asks about membership in a group that can refer to either inhabitants of the state ur its dominant ethnic group (Pole, Czech. Hungarian, Bulgarian, Slovenian, German). Thus the net effect of question wording and the distribution of titular ethnic groups is to slightly bias the survey results in favor of the civic-West/ethnic-East dichotomy.

5. The Canadian survey asked about ability to speak either English or French.

6. The data in all tables exclude the responses "Don't Know" and "Refused to Answer." 
Table 3

Ethnic Majority Views on Importance of Citizenship for National Membership

\begin{tabular}{lrc}
\hline Country & $N$ & Mean \\
\hline United States & 831 & 1.37 \\
Canada & 1073 & 1.51 \\
Norway & 1434 & 1.53 \\
Bulgaria & 891 & 1.58 \\
Great Britain & 822 & 1.58 \\
Slovakia & 1207 & 1.62 \\
Sweden & 1344 & 1.65 \\
Czech Republic & 870 & 1.66 \\
Slovenia & 940 & 1.70 \\
East Germany & 574 & 1.71 \\
Poland & 1506 & 1.72 \\
Latvia & 553 & 1.75 \\
West Germany & 1135 & 1.80 \\
Hungary & 960 & 1.84 \\
Spain & 968 & 1.84 \\
The Netherlands & 1990 & 1.87 \\
West & $\mathbf{8 4 6 2}$ & $\mathbf{1 . 6 5}$ \\
Central Europe & $\mathbf{1 7 0 9}$ & $\mathbf{1 . 7 7}$ \\
Eastern Europe & $\mathbf{6 9 2 7}$ & $\mathbf{1 . 6 9}$ \\
\hline
\end{tabular}

Note: $1=$ very important; $4=$ not important at all.

tries for this item, the West (mean $=1.65$ ) places slightly more importance on citizenship than Eastern Europe (1.69). ${ }^{7}$ This supports the relationship hypothesized by current theories, but the difference between the regions, although statistically significant, is very small (a later table investigates in more detail the statistical significance of regional differences). Looking more closely at the rankings, we find several surprises. Whereas the top three spots are occupied by Western states, Bulgaria, Slovakia, Slovenia, Poland, Latvia, and the Czech Republic stress citizenship more than do Spain and the Nether-

7. There are two options available for reporting the regional scores. One is to average the country scores for each region. This ensures that each country receives the same weight in the composite score. However, it is impossible to conduct any tests of statistical significance for regional differences using such scores. The other option is to pool all the respondents for each region and average their scores. The disadvantage here is that some countries are overrepresented due to their larger sample sizes, whereas others are underrepresented. This article chooses the latter method so that the statistical significance of differences between the regions may be assessed. Fortunately, the effects of overrepresentation and underrepresentation are very small, because the regional scores for each of the two methods are extremely close for all measurements in this article. 
lands. ${ }^{8}$ As well, Eastern Germany's score is lower than Western Germany's, contrary to expectations.

Another question asked respondents how important it is to feel that one is a member of the nation. This is a good measure of the civic notion of will and consent. Renan's (1994) famous quotation about a nation heing an "everyday plebiscite" refers precisely to this voluntary, subjective nature of civic nationhood (p. 17). For people who adhere to a cultural or ethnic conception of the nation, state of mind is less important. More central are objective factors such as descent and knowledge of a particular language. Whether an individual strongly feels himself or herself to be an " $X$ " or not, having parents of $X$ ethnicity or speaking $\mathrm{X}$ makes him an $\mathrm{X}$ in the ethnic and cultural conceptions. Table 4 indicates again that the dominant ethnic group in each country overall finds will/consent an important element of national identity. Greatly contradicting the idea of a West much more civic than Eastern Europe is the dominance of Eastern European countries in the top five spots. Indeed, the Eastern European average of 1.31 is lower than the West's average of 1.58. Whereas the higher scores in Central Europe compared with the West conform to the conventional wisdom, the relatively high scores of such Western countries as Great Britain, the Netherlands, and Spain do not.

Given the newness of the political and legal systems in all the states of the region, it would be surprising to find that Eastern Europeans deem respect for political institutions and law an important criterion for national membership. Yet as the data show in Table 5, the average score for Eastern Europe is just 1.77 , between very important and fairly important (although closer to the latter, of course). This score is higher than the West's (1.48), but considering that the age, stability, and effectiveness of Western political and legal institutions far outstrip those of Eastern Europe, the difference between these averages is quite small. It is quite difficult for the standard civic-West/ethnic-East paradigm to explain the fact that respondents in Latvia's 4-year-old state (in 1995), plagued with economic problems and corruption, deem respect for political institutions and law as important for nationhood as do respondents in the 219-year-old United States, arguably the most stable and wealthy country in the world (the .07 point difference here is not statistically significant). The same is true of Bulgaria's .05 point difference with Great Britain,

8. Because there are more than 130 dyadic combinations of countries for each of the tables in this article, reporting tests of statistical significance for the difference in average country scotes for each combination is not feasible. However, examination of these dyads using $t$ tests reveals a minimum level of difference between scores necessary to achieve statistical significance. For the 4-point scales, nearly all differences between countries that equal or exceed .10 are significant at the .05 level or better. For the 5-point scales, all differences in country averages that equal or exceed .12 are significant. 
Table 4

Ethnic Majority Views on Importance for National Membership of Feeling Oneself to be a Member of the Nation

\begin{tabular}{lrc}
\hline Country & $N$ & Mean \\
\hline Hungary & 973 & 1.17 \\
Bulgaria & 895 & 1.23 \\
Poland & 1519 & 1.32 \\
Slovakia & 1204 & 1.32 \\
Czech Republic & 865 & 1.34 \\
Canada & 1056 & 1.35 \\
Latvia & 552 & 1.39 \\
Slovenia & 929 & 1.46 \\
Norway & 1411 & 1.48 \\
United States & 825 & 1.51 \\
Sweden & 1311 & 1.58 \\
Spain & 971 & 1.63 \\
Great Britain & 818 & 1.73 \\
The Netherlands & 1969 & 1.73 \\
West Germany & 1126 & 1.85 \\
East Germany & 561 & 1.86 \\
West & $\mathbf{8 3 6 0}$ & $\mathbf{1 . 5 8}$ \\
Central Europe & $\mathbf{1 6 8 7}$ & $\mathbf{1 . 8 5}$ \\
Eastern Europe & $\mathbf{6 9 3 6}$ & $\mathbf{1 . 3 1}$ \\
\hline
\end{tabular}

Note: $1=$ very important: 4 = not important at all.

which also is not statistically significant. Furthermore, five Eastern European countries are ranked higher than Spain and the Netherlands, and the differences are statistically significant in each case except the comparisons with the Czech Republic. Thus although the regional averages for this item conform to the conventional view (civicness of West $>$ Central Europe $>$ Eastern Europe), the absolute values of the Eastern European scores and their position relative to some Western states are inconsistent with that view.

Finally, the survey data can measure support for a territorial conception of nationhood in the 16 cases. But first we must discuss how exactly territory is a basis for national unity in a civic state. In his description of civic nation building in the Third World, Smith (1991) explains that "'living together' and being 'rooted' in a particular terrain and soil become the criteria for citizenship and the bases of political community" (p. 117). Presumably those who have lived a long time in a state are more rooted in the territory and thus are more "authentic" members than new residents. Similarly, someone born in a territory may be seen as more attached to it than an immigrant. Using territory as a criterion of national membership is inclusive in that anybody who is born 
Table 5

Ethnic Majority Views on Importance of Respect for Political Institutions and Law for National Membership

\begin{tabular}{lrc}
\hline Country & $N$ & Mean \\
\hline Sweden & 1351 & 1.17 \\
Norway & 1429 & 1.23 \\
Canada & 1058 & 1.36 \\
United States & 823 & 1.42 \\
Latvia & 552 & 1.49 \\
West Germany & 1129 & 1.53 \\
Great Britain & 814 & 1.56 \\
Bulgaria & 864 & 1.61 \\
East Germany & 555 & 1.66 \\
Slovakia & 1187 & 1.66 \\
Slovenia & 921 & 1.67 \\
Czech Republic & 832 & 1.75 \\
Spain & 965 & 1.77 \\
The Netherlands & 1940 & 1.80 \\
Poland & 1451 & 1.85 \\
Hungary & 934 & 2.19 \\
West & $\mathbf{8 3 7 9}$ & $\mathbf{1 . 4 8}$ \\
Central Europe & $\mathbf{1 6 8 4}$ & $\mathbf{1 . 5 8}$ \\
Eastern Europe & $\mathbf{6 7 4 0}$ & $\mathbf{1 . 7 7}$ \\
\hline
\end{tabular}

Note: 1 = very important; $4=$ not important at all.

or lives a long time in a country meets this criterion-regardless of ethnicity, religion, class, race, and so forth. It is exclusive, however, in that some (those who are newly resident) or all immigrants are not considered fully part of the national community.

The survey data indicate that dominant ethnic groups in the Eastern European states are generally more supportive of a territorial notion of national identity than in the Western states, although both regions are supportive in an absolute sense (see Tables $6 \& 7$ ). In fact, only one country, Canada, has a majority of respondents who do not stress the importance of one of the two types of territoriality. In addition, both regions place slightly more importance on length of residence than on birth, the latter of course being the harder standard to meet (i.e., it is more exclusive). Particularly interesting is the strong emphasis given to territoriality by those majority ethnic groups that have diasporas in other countries. For example, these data suggest that most Germans in the two Germanies, Czechs in the Czech Republic, Hungarians in Hungary, Slovaks in Slovakia, and so on do not think that their ethnic brethren in other countries in the region are "real" members of the nation-a sign 
Table 6

Ethnic Majority View's on Importance of Spending Most of One's Life in Country for National Membership

\begin{tabular}{lrc}
\hline Country & $N$ & Mean \\
\hline Bulgaria & 882 & 1.65 \\
Czech Republic & 862 & 1.73 \\
Hungary & 963 & 1.79 \\
Latvia & 554 & 1.81 \\
Poland & 1494 & 1.82 \\
Great Britain & 806 & 1.84 \\
Spain & 972 & 1.84 \\
Slovenia & 937 & 1.86 \\
Slovakia & 1204 & 1.89 \\
United States & 825 & 1.93 \\
Norway & 1418 & 1.99 \\
East Germany & 562 & 2.04 \\
Sweden & 1322 & 2.15 \\
West Germany & 1129 & 2.17 \\
The Netherlands & 1971 & 2.27 \\
Canada & 1069 & 2.34 \\
West & $\mathbf{8 3 8 4}$ & $\mathbf{2 . 0 9}$ \\
Central Europe & $\mathbf{1 6 9 1}$ & $\mathbf{2 . 1 3}$ \\
Eastern Europe & $\mathbf{6 8 9 7}$ & $\mathbf{1 . 8 0}$ \\
\hline
\end{tabular}

Note: 1 = very important; 4 = not important at all.

that ethnic nationhood is weak in the region. Also, for those Westerners who consider a stress on territoriality a mostly exclusive and negative phenomenon, the importance that Britain, Spain, and even the United States-the land par excellence of immigration - place on birth must be disconcerting.

Just as the survey questions show that civic sources of national identity are stronger in Eastern Europe than is usually supposed, they also show that the cultural bases of national identity are stronger in the West than is usually supposed.

When asked about the role of speaking the country's dominant language in constituting nationhood, respondents in all countries, including those in the West, generally think language is important, with country scores ranging from 1.25 to 1.88 (see Table 8). Although Eastern European scores (1.39) are lower on average than Western ones (1.49), the difference is very small. There are some unexpected scores from the standpoint of the civic-West/ ethnic-East stereotype. The United States, the Netherlands, Sweden, and Norway all have scores of 1.38 or lower. Also, five of the seven Western states place greater importance on language than both halves of Germany, with all 
Table 7

Ethnic Majority Views on Importance of Being Born in Country for National Membership

\begin{tabular}{lrl}
\hline Country & $N$ & Mean \\
\hline Bulgaria & 892 & 1.54 \\
Great Britain & 830 & 1.71 \\
Poland & 1504 & 1.79 \\
Spain & 976 & 1.87 \\
Czech Republic & 852 & 1.94 \\
Slovenia & 940 & 1.95 \\
Latvia & 559 & 1.96 \\
Hungary & 960 & 2.01 \\
United States & 823 & 2.09 \\
Slovakia & 1205 & 2.11 \\
Norway & 1433 & 2.14 \\
East Germany & 579 & 2.22 \\
The Netherlands & 1994 & 2.35 \\
West Germany & 1145 & 2.38 \\
Sweden & 1346 & 2.39 \\
Canada & 1064 & 2.54 \\
West & $\mathbf{8 4 6 6}$ & $\mathbf{2 . 2 0}$ \\
Central Europe & $\mathbf{1 7 2 4}$ & $\mathbf{2 . 3 2}$ \\
Eastern Europe & $\mathbf{6 9 1 1}$ & $\mathbf{1 . 9 0}$ \\
\hline
\end{tabular}

Note: $1=$ very important $4=$ not important at all.

differences statistically significant. Because language has historically played such an important role in German identity, this is particularly good evidence of the depth of culturally grounded national identities in the West.

The ISSP survey also asked about the role of religion in national identity (see Table 9). In contrast to all the previous items, in most of the 16 cases, a majority of respondents does not consider religion to be an important criterion for national membership (scores exceed 2.5). The data on the importance of religion present a similar ranking pattern as does language, with Eastern Europe leading the pack, followed by the West, and then Central Europe. However, several Western states again scored lower than several Eastern European states. The United States, Spain, and Britain all place greater stress on religion than Slovenia, Slovakia, and the Czech Republic. The nearly identical scores of the supposedly civic United States and ethnic Poland are particularly noteworthy, especially given the key role Catholicism and the Catholic Church have played in the national revival in Poland during and since communism.

A final measure of the cultural component of national identity comes from the following: "Now we would like to ask you a few questions about minori- 
Table 8

Ethnic Majority Views on Importance of Ability to Speak Dominant Language for National Membership

\begin{tabular}{lrc}
\hline Country & $N$ & Mean \\
\hline Hungary & 970 & 1.25 \\
Czech Republic & 869 & 1.29 \\
Norway & 1434 & 1.30 \\
Slovakia & 1209 & 1.33 \\
Slovenia & 946 & 1.33 \\
Sweden & 1353 & 1.33 \\
Latvia & 555 & 1.36 \\
The Netherlands & 2005 & 1.38 \\
United States & 832 & 1.38 \\
Bulgaria & 889 & 1.47 \\
Great Britain & 828 & 1.47 \\
Poland & 1519 & 1.57 \\
West Germany & 1144 & 1.57 \\
East Germany & 576 & 1.62 \\
Spain & 972 & 1.87 \\
Canada & 1068 & 1.88 \\
West & $\mathbf{8 4 9 2}$ & $\mathbf{1 . 4 9}$ \\
Central Europe & $\mathbf{1 7 2 0}$ & $\mathbf{1 . 5 9}$ \\
Eastern Europe & $\mathbf{6 9 5 7}$ & $\mathbf{1 . 3 9}$ \\
\hline
\end{tabular}

Note: 1 = very important; 4 = not important at all.

ties in [respondent's country]. How much do you agree or disagree with the following [statement]: It is impossible for people who do not share the customs and traditions [of respondent's country] to become fully [e.g., British, German, Hungarian, etc.].' Respondents used a 5-point agree/disagree scale (agree strongly, agree, neither agree nor disagree, disagree, disagree strongly). Note that in contrast to the previous questions, a score less than 3.0, not 2.5, indicates that a majority of respondents finds this element of national identity important (i.e., agrees with the statement). In only 3 of the 16 cases does a majority not agree that sharing the traditions and customs of a country is necessary for national membership (see Table 10). Consistent with the civicWest/ethnic-East argument, Eastern Europe (mean $=2.39$ ), on the whole, emphasizes customs and traditions more than the West (2.62), although Norway, the Netherlands, and Sweden place more importance on this item than four Eastern European countries, with all differences statistically significant. Again, the difference between the West and Eastern Europe, although statistically significant, is small: .23 point on a 5-point scale. In addition, the two 
Table 9

Ethnic Majority Views on Importance of Being a Believer in Dominant Religion for National Membership

\begin{tabular}{lcc}
\hline Country & $N$ & Mean \\
\hline Bulgaria & 862 & 1.80 \\
United States & 816 & 2.41 \\
Poland & 1455 & 2.43 \\
Spain & 965 & 2.64 \\
Hungary & 960 & 2.79 \\
Latvia & 525 & 2.80 \\
Slovenia & 913 & 2.82 \\
Great Britain & 810 & 2.83 \\
West Germany & 1112 & 2.92 \\
Slovakia & 1176 & 3.09 \\
Canada & 1036 & 3.12 \\
Norway & 1328 & 3.13 \\
Czech Republic & 832 & 3.14 \\
East Germany & 542 & 3.20 \\
Sweden & 1297 & 3.30 \\
The Netherlands & 1945 & 3.58 \\
West & $\mathbf{8 1 9 8}$ & $\mathbf{3 . 1 0}$ \\
Central Europe & $\mathbf{1 6 5 4}$ & $\mathbf{3 . 0 1}$ \\
Eastern Europe & $\mathbf{6 7 2 4}$ & $\mathbf{2 . 6 9}$ \\
\hline N & & \\
\hline
\end{tabular}

Note: 1 = very important; 4 = not important at all.

Germanies place slightly less importance on this cultural component (2.88) than do Western countries-contrary to established views.

This article's analysis of the ISSP's direct measures of national identity permits several conclusions. First, for every measure, there are some Eastern European countries that are more civic and less cultural than some Western countries. Second, the general pattern of support in the West, Eastern Europe, and Central Europe for the civic and cultural content of identity is similar. Table 11 demonstrates that a majority of respondents in all three regions agree on whether or not a given component of national identity is important. For example, on the question on citizenship, the average scores of the Western (1.65), Eastern European (1.69), and Central European (1.77) samples are all less than 2.5-the midway point on the 4-point scale-signifying that most people in each region find this component of national identity important. This pattern of basic regional agreement is found for all eight direct measures of national identity in the study. These results should caution scholars against characterizing these three regions as fundamentally different in their concepts of nationhood. 
Table 10

Ethnic Majority Views on Need for Minorities to Share Country's Customs and Traditions to Become Members of Nation

\begin{tabular}{lrc}
\hline Country & $N$ & Mean \\
\hline Bulgaria & 896 & 1.35 \\
Latvia & 534 & 1.96 \\
Norway & 1414 & 2.27 \\
Slovenia & 908 & 2.33 \\
The Netherlands & 1965 & 2.36 \\
Sweden & 1307 & 2.37 \\
Great Britain & 821 & 2.52 \\
Hungary & 938 & 2.54 \\
Czech Republic & 830 & 2.55 \\
Poland & 1354 & 2.56 \\
East Germany & 528 & 2.79 \\
Spain & 898 & 2.85 \\
West Germany & 1080 & 2.92 \\
Slovakia & 1185 & 3.00 \\
United States & 782 & 3.09 \\
Canada & 1063 & 3.39 \\
West & $\mathbf{8 2 5 1}$ & $\mathbf{2 . 6 2}$ \\
Central Europe & $\mathbf{1 6 0 8}$ & $\mathbf{2 . 8 8}$ \\
Eastern Europe & $\mathbf{6 6 4 5}$ & $\mathbf{2 . 3 9}$ \\
\hline
\end{tabular}

Note: 1 = agree strongly; 5 = disagree strongly.

The civic-West/ethnic-East argument can also be evaluated by more narrowly comparing the intensity of support for a given component of national identity in the three regions. Elements of this argument that are confirmed by the direct survey measures are marked by an $\mathrm{X}$ in Table 12. Comparing the West and Eastern Europe (Column I), the standard argument correctly predicts greater support in Eastern Europe for the three cultural components of national identity, but correctly predicts greater support in the West for civic identity in just two of the five components-citizenship and respect for political institutions and law. Furthermore, for each component, the differences in average scores for the two regions (shown in parentheses) are small. The standard interpretation also predicts a stronger civic and weaker cultural identity in the West than in Central Europe. The data support this claim in all of the civic items (one of which, Territory - Long Residence, is not statistically significant) but in just one of the cultural items (Column II). We should also find the two Germanies to have stronger civic and weaker cultural identities than Eastern Europe. This holds true for all the cultural items but for just one of the civic items (Column III). Next, the two Germanies provide a nice 
Table 11

Regions Where Majority of Respondents Finds Given Component of National Identity Important

\begin{tabular}{lccc}
\hline Component of National Identity & West & $\begin{array}{l}\text { Central } \\
\text { Europe }\end{array}$ & $\begin{array}{l}\text { Eastern } \\
\text { Europe }\end{array}$ \\
\hline Civic & & & \\
Will & $\mathrm{X}$ & $\mathrm{X}$ & $\mathrm{X}$ \\
Citizenship & $\mathrm{X}$ & $\mathrm{X}$ & $\mathrm{X}$ \\
Respect institutions/law & $\mathrm{X}$ & $\mathrm{X}$ & $\mathrm{X}$ \\
Territory-birth & $\mathrm{X}$ & $\mathrm{X}$ & $\mathrm{X}$ \\
Territory-long residence & $\mathrm{X}$ & $\mathrm{X}$ & $\mathrm{X}$ \\
Cultural & & & $\mathrm{X}$ \\
Language & $\mathrm{X}$ & $\mathrm{X}$ & $\mathrm{X}$ \\
Religion & & $\mathrm{X}$ & $\mathrm{X}$ \\
Traditions & $\mathrm{X}$ & $\mathrm{X}$ & \\
\hline
\end{tabular}

Note: $\mathrm{X}$ indicates that the regional average is less than 2.5 for each item (except Traditions, where average is less than 3.0 ).

quasi-experiment on the effect of communism on national identity. The standard argument predicts stronger civic and weaker cultural identity in West Gcrmany than in East Germany. However, only three of the eight direct measures of national identity conform to this expectation, and one of those (Will) is not statistically significant (Column IV). In all, of the 32 elements of the civic-West/ethnic-East stereotype evaluated in Table 12, only 16 are confirmed by statistically significant measures. And even for these 16 elements, the regional differences are very small. The average point differential in these 16 instances for the measures using a 4-point scale is .18, and the average differential for the 5-point Tradition measure is . 28 .

\section{INDIRECT MEASURES OF NATIONAL IDENTITY}

In addition to investigating support for various contents of national identity by looking at mass attitudes toward criteria for membership in the nation, we can examine attitudes toward key policy issues: cultural assimilation and immigration.

Two questions from the ISSP survey assess the majority's attitude toward minority assimilation and the state's role in promoting or resisting it. One question read,

Some people say that it is better for a country if different racial and ethnic groups maintain their distinct customs and traditions. Others say that it is better 
Table 12

Elements of the Civic-West/Ethnic-East Argument That Are Confirmed by the Direct Measures of National Identity (indicated by X)

\begin{tabular}{|c|c|c|c|c|}
\hline $\begin{array}{l}\text { Component of } \\
\text { National Identity }\end{array}$ & $\begin{array}{c}\text { I } \\
\text { W vs. EE }\end{array}$ & $\begin{array}{c}\text { II } \\
\text { W vs. CE }\end{array}$ & $\begin{array}{c}\text { III } \\
\text { CE vs. EE }\end{array}$ & $\begin{array}{c}\text { IV } \\
\text { WG vs. EG }\end{array}$ \\
\hline \multicolumn{5}{|l|}{ Civic } \\
\hline Will & $(.27)^{* * *}$ & $X(.27)^{* * *}$ & $(.54)^{* * *}$ & $X(.01)$ \\
\hline Citizenship & $X(.04)^{* * *}$ & $X(.12)^{* * *}$ & $(.08)^{* * *}$ & $(.09)^{*}$ \\
\hline Respect institutions/law & $\mathrm{X}(.29)^{* * *}$ & $X(.10)^{* * *}$ & $X(.19)^{* * *}$ & $\mathrm{X}(.13)^{* * *}$ \\
\hline Territory-birth & $(.30)^{* * *}$ & $\mathrm{X}(.12)^{* * *}$ & $(.42)^{* * *}$ & $(.16)^{* *}$ \\
\hline Territory-long residence & $(.29)^{* * *}$ & $X(.04)$ & $(.33)^{* * *}$ & $(.13)^{* *}$ \\
\hline \multicolumn{5}{|l|}{ Cultural } \\
\hline Language & $X(.10)^{* * *}$ & $(.10)^{* * *}$ & $X(.20)^{* * *}$ & $(.05)$ \\
\hline Religion & $X(.41)^{* * *}$ & $X(.09)^{* *}$ & $X(.32)^{* * *}$ & $(.28)^{k * *}$ \\
\hline Traditions & $X(.23)^{* * *}$ & $(.26)^{* * *}$ & $X(.49)^{* * *}$ & $X(.13)^{*}$ \\
\hline
\end{tabular}

Note: $\mathrm{I}$ : Civic identity $\mathrm{W}>\mathrm{EE}$, Cultural identity $\mathrm{EE}>\mathrm{W}$; II: Civic identity $\mathrm{W}>\mathrm{CE}$, Cultural identity $\mathrm{CE}>$ W; III: Civic identity $\mathrm{CE}>\mathrm{EE}$, Cultural identity $\mathrm{EE}>\mathrm{CE}$; IV: Civic identity WG $>$ EG, Cultural identity EG > WG. W = West; $\mathrm{EE}=$ Eastern Europe; $\mathrm{CE}=$ Central Europe; WG = West Germany; EG = East Germany. Point differentials between regional averages are given in parentheses. Based on 4-point scales for all items except Traditions, which used a 5-point scale.

${ }^{*} p \leq .05 . * * p \leq .01 . * * * p \leq .001$.

if these groups adapt and blend into the larger society. Which of these views comes closer to your own?

1. It is better for society if groups maintain their distinct customs and traditions.

2. It is better if groups adapt and blend into the larger society.

This question ascertains the respondent's general support for assimilation. The results show striking differences between the Western and Eastern European countries in the sample, with the former preferring minority assimilation at substantially higher rates than the latter (see Table 13). The countries ranked highest in support for assimilation are all Western countries, whereas the countries ranked lowest are all Eastern and Central European countries. ${ }^{9}$ A majority of respondents in every Western country except Spain desires assimilation of minorities into the dominant culture. Based on the earlier discussion, this result is good evidence that cultural national identity is strong in the West. In addition, majorities in every Eastern and Central European country except Bulgaria are against assimilation. But one must be careful in draw-

9. Chi-square testing indicates that all differences between countries in support for assimilation equal to or greater than five percentage points are statistically significant. 
Table 13

Ethnic Majority Attitudes Toward Cultural Assimilation of Minorities

\begin{tabular}{|c|c|c|c|}
\hline Country & $N$ & $\begin{array}{l}\% \text { Against } \\
\text { Assimilation }\end{array}$ & $\begin{array}{c}\% \text { For } \\
\text { Assimilation }\end{array}$ \\
\hline Latvia & 483 & 70 & 30 \\
\hline East Germany & 451 & 61 & 39 \\
\hline Hungary & 894 & 60 & 40 \\
\hline Slovakia & 1068 & 58 & 42 \\
\hline Slovenia & 766 & 54 & 46 \\
\hline Poland & 956 & 52 & 48 \\
\hline Spain & 856 & 52 & 48 \\
\hline West Germany & 897 & 52 & 48 \\
\hline Czech Republic & 730 & 50 & 50 \\
\hline Bulgaria & 780 & 48 & 52 \\
\hline United States & 599 & 40 & 60 \\
\hline Canada & 889 & 36 & 64 \\
\hline The Netherlands & 1660 & 29 & 71 \\
\hline Norway & 1208 & 24 & 76 \\
\hline Great Britain & 702 & 19 & 81 \\
\hline Sweden & 1150 & 18 & 82 \\
\hline West & 7063 & 30 & 70 \\
\hline Central Europe & 1348 & 55 & 45 \\
\hline Eastern Europe & 5677 & 55 & 45 \\
\hline
\end{tabular}

ing inferences from this with regard to national identity. Resistance to assimilation may be a sign of ethnic identity or civic identity. Eastern and Central European respondents, who represent majority ethnic groups, might think that minorities can never become part of the nation regardless of what culture they adopt, because they are of the wrong ancestry or race. Thus resistance to assimilation may reflect exclusionary attitudes based on ethnicity.

Another measure of mass policy preferences in the cultural sphere does allow distinguishing between support for ethnic and civic concepts of nationhood. Respondents in each country were asked how much they agree or disagree with this statement (using a 5-point agree-disagree scale): "Ethnic minorities should be given government assistance to preserve their customs and traditions." Yet again, the data are highly inhospitable to the standard civic-West/ethnic-East argument (see Table 14). The five most multicultural countries are Eastern and Central European, whereas the six least multicultural are Western. For all the talk of multiculturalism in the West, particularly the United States and Canada, the weak desire to aid ethnic minority cultures in these countries relative to post-communist Europe poses a great challenge to any scholar adhering to the conventional wisdom on ethnic and civic 
Table 14

Ethnic Majority Support for Government Assistance to Preserve Minority Cultures

\begin{tabular}{lrc}
\hline Country & $N$ & Mean \\
\hline Hungary & 954 & 1.91 \\
Slovenia & 879 & 2.26 \\
Poland & 1395 & 2.28 \\
East Germany & 552 & 2.34 \\
Latvia & 520 & 2.44 \\
Spain & 877 & 2.54 \\
Slovakia & 1152 & 2.65 \\
Czech Republic & 800 & 2.86 \\
Bulgaria & 828 & 2.99 \\
West Germany & 1070 & 2.99 \\
The Netherlands & 1925 & 3.41 \\
Sweden & 1245 & 3.46 \\
Norway & 1374 & 3.56 \\
Great Britain & 812 & 3.69 \\
United States & 784 & 3.75 \\
Canada & 1050 & 3.84 \\
West & $\mathbf{8 0 6 7}$ & $\mathbf{3 . 4 7}$ \\
Central Europe & $\mathbf{1 6 2 2}$ & $\mathbf{2 . 7 7}$ \\
Eastern Europe & $\mathbf{6 5 2 7}$ & $\mathbf{2 . 4 6}$ \\
\hline
\end{tabular}

Note: 1 = agree strongly; 5 = disagree strongly.

nations. A desire for governmental support for ethnic minority cultures is not consistent with an ethnic national identity centered on the dominant or titular group.

Another major policy issue that can shed light on conceptions of national identity in a country is immigration. ISSP respondents were asked the following:

Do you think the number of immigrants to [respondent's country] should ...

1. Be increased a lot.

2. Be increased a little.

3. Remain the same as it is.

4. Be reduced a little.

5. Be reduced a lot.

Civic identities should lead to greater openness to immigration, whereas cultural and ethnic identities should be more restrictive. Unfortunately, the data do not permit taking into account how the cultural or ethnic background of 
Table 15

Ethnic Majority Support for Increasing/Decreasing Immigration Rates

\begin{tabular}{lrl}
\hline Country & $N$ & Mcan \\
\hline Spain & 856 & 3.40 \\
Canada & 950 & 3.43 \\
The Netherlands & 1888 & 3.84 \\
Poland & 1092 & 3.84 \\
Norway & 1363 & 3.86 \\
United States & 723 & 3.92 \\
Slovenia & 893 & 3.99 \\
Sweden & 1272 & 4.01 \\
Slovakia & 1001 & 4.02 \\
Great Britain & 800 & 4.09 \\
Czech Republic & 789 & 4.17 \\
Bulgaria & 608 & 4.23 \\
West Germany & 1063 & 4.26 \\
East Germany & 541 & 4.34 \\
Hungary & 935 & 4.42 \\
Latvia & 511 & 4.46 \\
West & $\mathbf{7 8 5 2}$ & $\mathbf{3 . 8 1}$ \\
Central Europe & $\mathbf{1 6 0 4}$ & $\mathbf{4 . 2 8}$ \\
Eastern Europe & $\mathbf{5 8 2 8}$ & $\mathbf{4 . 1 3}$ \\
\hline
\end{tabular}

Note: $1=$ increased a lot $5=$ decreased a lot .

immigrants affects respondents' attitudes toward their entry. As the data demonstrate (see Table 15), most respondents in all countries prefer that immigration be scaled back. To the extent that attitudes toward immigration reflect national identity, the data for the most part conform to the standard civicWest/ethnic-East interpretation. The average score of Eastern Europe is 4.13, whereas that of the West is 3.81. Although the difference is in the expected direction and statistically significant, the .32 gap is small considering the 5-point scale used. Not consistent with the standard view is the fact that the two Germanies express more resistance to immigration than does Eastern Europe. Given that most Westerners wish to scale back immigration, the best interpretation of this measurement of identity is not that the West more strongly supports civic nationhood than Eastern Europe, but that it is slightly less supportive of ethnic or cultural nationhood.

The indirect measures thus point in different directions from the standpoint of evaluating the civic-West/ethnic-East argument. Consistent with the conventional wisdom, attitudes toward immigration point to the greater strength of cultural or ethnic identities in Eastern Europe than in the West. Yet attitudes toward assimilation and multiculturalism contradict the standard 
argument, pointing toward stronger civic and weaker cultural identities in Eastern Europe than in the West. In terms of the normative concerns of many scholars who employ the standard civic/ethnic and West/East dichotomies, Eastern Europe is more tolerant of its internal minorities than is the West, whereas the West is more tolerant of immigrant minorities than is Eastern Europe. In addition, East Germany demonstrates greater support for internal minority cultures than does West Germany, yet another indication that experience with communism does not seem to stimulate the cultivation of ethnic and cultural national identities. Although East Germany is less welcoming of immigrants than West Germany, the difference is extremely small (.08) and not statistically significant. Like the direct measures of national identity, the indirect measures overall present a much more complex picture of national identification in the three regions than portrayed by the civic-West/ethnicEast argument, with the West more cultural than is usually supposed and Central and Eastern Europe more civic.

\section{EXPLAINING STRONG CULTURAL NATIONAL IDENTITY IN THE WEST}

Why should it come as no surprise that majority ethnic groups in the Western countries harbor a relatively strong cultural national identity, especially as reflected in their views toward language and cultural assimilation? There are several reasons.

First, both of the main sides in the debate over the origins and modernity of nations imply a strong role for culture as a basis for national identity in the West. Smith's (1986) argument that nations have ancient "ethnic cores" around which nations are constructed clearly demands a great role for the cultural components of national identity. A nation founded on the culture, symbols, myths, and memories of a dominant ethnic group is likely to retain its culturally based identity for a very long time. Smith writes that the earliest cases of the Western model (England, France, Spain, Holland, Sweden, Russia) were "ethnic states" that were gradually transformed into nations through economic unification, territorial centralization, provision of equal legal rights, and growth of mass public education (p. 138). It is interesting that Kohn's argument begins with assumptions similar to Smith's. Recall that in Kohn's Westem model, the state encompassed a relatively culturally homogeneous population, which the state then forged into a nation. The strong match between ethnography and political boundaries in Kohn's Western model is akin to Smith's ethnic core of modern nations. But Kohn did not follow his initial assumption to its logical conclusion-that relative cultural 
homogencity in a state would be a strong force binding the people together into a nation. By the logic of both Kohn's and Smith's approaches, since the Western nation's inception, culture has been prominent in uniting and distinguishing a large proportion of the population of a state.

Gellner (1983) and other "modernists" disagree with Smith's contention about the ethnic origins of nations. Gellner instead explains the rise of nations through a functional argument whereby states intentionally forged national unity to meet the demands of industrial development. The state, primarily through public education, pursued cultural homogenization of its population to create a mobile workforce able to communicate with strangers. Another modernist, Benedict Anderson, focuses not on industrialization but the rise of print capitalism in forging national consciousness. In Anderson's (1983) view, mass communication stimulated the diffusion of a common culture based on a vernacular language. In each theory, culture plays a key role in uniting a large proportion of a state's population, just as in Smith's version. The difference is primarily one of timing. If Smith's argument means that cultural and civic elements should coexist from the start of Western states' national development, Gellner's and Anderson's arguments imply that the cultural elements should be weak at the start of national development and then gain strength as industrialization and mass communications developed over the 19th and 20th centuries.

A second explanation for the current strength of the cultural components of national identity in the West centers on the inability of civic components of national identity to provide sufficient unity in a state. To the extent that a civic identity is rationalistic and voluntary, it is unlikely to cultivate an attachment to the nation with the great emotional resonance that ethnic and cultural elements provide. But the main reason that civic components of nationhood fall short in their ability to evoke emotional attachment to the nation is because most civic components of nationhood are external to the individual, whereas ethnic and cultural components are internal. Territory, political institutions and rights, and citizenship exist outside the individual, whereas ancestry, race, religion, language, and traditions are a direct part of a person's physical and psychological makeup. As a result, the intensity of attachment to communities founded predominantly on the latter will likely exceed those founded predominantly on the former. The dismal record of civic-territorial nation building in many postcolonial multiethnic states in the Third World is a testament to the weakness of civic nationalism unsupported by elements of ethnic or cultural nationhood at the statewide level. Using functionalist logic similar to Gellner's, a case can be made that Western states for most of the past two centuries have promoted a homogeneous linguistic and cultural identity precisely due to the ability of culture to provide cohesion for popula- 
tions in an environment in which civic elements of nationhood alone were not up to the task.

Finally, all social identities, including national ones, require that the social unit be differentiated from other units. Purely or predominantly civic-based national identities are unable to provide a sufficiently high degree of differentiation in the modern world. The very universalistic nature of civic nationalism that many applaud is a reason for its inability to provide the sole or even overwhelming basis for identification in the West. Not only is it relatively easy for states to make citizenship an important criterion for national membership, but it is exceedingly common. Similarly, all states have territory, and making attachment to that territory a criterion for national membership is also easy and ubiquitous. There is more room for national variation in political rights and institutions, and belief in political principles. However, the spread of democratic government and ideology in the past two centuries has greatly reduced this variation. In this context, culture, which varies substanlially from place to place, grows in importance for its ability to distinguish one Western nation from another and from non-Western nations.

\section{EXPLAINING CIVIC NATIONAL IDENTITY IN EASTERN EUROPE}

How is it that the data show such strong support for civic components of national identity among majority ethnic groups in Eastern Europe?

Those observers who expect nationalism in Eastern Europe to be mostly of the ethnic variety neglect to take into consideration the enormous influence and prestige of the civic model of the nation. Whereas Western nations have long been based on culture, the rhetoric emanating from these countries stressing the centrality of territory, citizenship, and political institutions to nationhood has been strong. This civic conception of the nation diffused to the non-West, in large part due to wealth and power of the West. Western ideas at the end of the 18th century about the state being the representative and embodiment of the nation have become commonplace, precisely because of the military and economic success of what is presented as the civicnation-state model. In this context, cthnonational groups look to statchood, or at least a degree of political autonomy within an existing state, as a means of defending and promoting their culture, identity, and interests. Thus as soon as Hungarians, Czechs, Latvians, and so forth become majority and titular groups in independent states, free of Soviet domination, attachment to and membership in the nation quickly become measured against a person's relation to the state-its territory, institutions, laws, and the like. 
A second, and related, reason for the strength of civic-based national identities in Eastern Europe is the historical experience of many of these countries with statehood. Of the seven Eastern European titular groups in this sample, five have enjoyed independent statehood prior to indirect or direct Soviet domination: Bulgarians, Poles, Hungarians. Czechs, and Latvians. The other two groups, Slovenians and Slovaks, attained nominal sovereignty in territorialadministrative units of the Yugoslavian and Czechoslovakian federations, respectively. Consequently, contemporary national identity did not develop solely in the context of struggle against political borders in Eastern Europethe dimension stressed by Kohn and others. It also developed around political borders that overlapped to a large degree with ethnic and cultural borders. Furthermore, Eastern European ethnic groups' national mythologies celebrate their earlier periods of statehood as golden ages. With the collapse of communism, the independent state and its institutions and territory are looked to as vehicles of national renaissance.

Finally, another aspect of Kohn's original argument provides an insight into the strength of civic national identity in Eastern Europe. Kohn wrote that nationalism in Central and Eastern Europe developed in reaction to the French invasions during the Napoleonic Wars and the universalist ideology of Western liberalism. To counter this, Central and Eastern Europe looked to their own unique historical and cultural heritage as the basis of national identity. This same argument can be adapted to post-Communist Eastern Europe to explain the strength of civic components of national identity there. Modern national identities in this region developed in opposition to Soviet domination and its universalist communist ideology. As Soviet and communist rule weakened and finally collapsed, people in the region again rallied around their heritage, but now they interpreted this heritage as fundamentally democratic - in contrast to that of their imperial overlord. In constructing national identity and asserting national autonomy, most titular ethnic groups in the region consequently underscored democratic principles flouted during the communist period-the rule of law, political equality, and minority rights. Therefore, whereas the reactive nature of Eastern European nationalism in the 19 th century may have led to a stress on ethnic and cultural components of national identity, in the late 20 th century it led to a stress on civic components.

\section{CONCLUSION}

The empirical analysis in this article demonstrates that the traditional civic-West/ethnic-East argument is a gross simplification of concepts of 
nationhood in the West, Central Europe, and Eastern Europe. Although some survey measures examined herein support the argument, an equal number do not. Furthermore, even when the argument is true, it is only weakly true, as the differences in national identity between the regions are small and there is a substantial degree of diversity within each region. Overall, the data suggest that imperial and communist rule have not pushed Eastern European nationhood in a strongly cultural direction while greatly weakening civicness. And whereas most of the West has a long tradition of democracy and relatively strong and stable political institutions, cultural conceptions of nationhood are alive and well, and support for multiculturalism is relatively weak. The data reveal an interesting tension between policies adopted by many of the states in the sample and the identities of their inhabitants. For example, although Canada has adopted an official policy of multiculturalism, Anglophones there are more supportive of minority assimilation than are majority groups throughout Central and Eastern Europe. Likewise, although Germany until 1999 had a citizenship law more ethnically discriminatory than that of any Western democracy, ethnic Germans themselves place greater importance on developing minority cultures and less importance on language and traditions as criteria of national membership than do most other Western majority groups in this study. This suggests that scholars must be careful not to overestimate the ability of states to shape mass national identities.

Last, this article has several limitations that must be noted. First, it examines current patterns of national identity. It is possible, even likely, that historically the groups under study here cxhibitcd different degrees of ethnic/ cultural/civic components in their national identity than they do now. Second, the analysis relies on just one dataset from 1995-1996 that may reflect short-term trends away from long-term patterns more consistent with the conventional wisdom. For example, ethnic conflict in Yugoslavia and the former USSR may have temporarily delegitimized ethnic and cultural notions of national identity in Central and Eastern Europe. Third, patterns of support for ethnic/cultural versus civic notions of national identity may systematically differ for masses and elites, with elite views more consistent with the civic-West/ethnic-East pattern. Further study of a wide range of political elites in each state will tell if there is a mass-elite gap in identification on this score. Fourth, the limitations of the survey data did not permit a rigorous assessment of the differences in support for the strictly ethnic content of national identity in the cases under study, or analysis of the role of political principles in generating civic identities. Additional multicountry surveys should be conducted to ascertain whether ancestry, race, and political ideology play a different role in national identity in the West, Central Europe, and Eastern Europe. Finally, much work remains to be done in explaining the dif- 
ferences in national identity found among the individual countries in this study. Factors such as the settlement patterns of a nation's main ethnic groups, the cultural distance between these groups, the existence and size of diaspora groups outside the country, and levels of immigration all may affect the strength of ethnic/cultural/civic conceptions of national identity and thus merit study.

\section{REFERENCES}

Alter, Peter. (1994). Nationalism (2nd ed.). London: Edward Arnold.

Anderson, Benedict. (1983). Imagined communities: Reflections on the origins and spread of nationalism. London: Verso.

Brubaker, Rogers. (1992). Citizenship and nationhood in France and Germany. Cambridge, MA: Harvard University Press.

Brubaker, Rogers. (1996). Nationalism reframed: Nationhood and the national question in Europe. Cambridge: Cambridge University Press.

Calhoun, Craig. (1997). Nationalism. Minneapolis: University of Minnesota Press.

Gellner, Ernest. (1983). Nations and nationalism. Ithaca, NY: Cornell University Press.

Gellner, Ernest. (1992). Nationalism in a vacuum. In A. J. Motyl (Ed.), Thinking theoretically about Soviet nationalities: History and comparison in the study of the USSR (pp. 243-254). New York: Columbia University Press.

Ignatieff, Michael. (1993). Blood and belonging: Journeys into the new' nationalism. New York: Farrar, Straus, Giroux.

Kohn, Hans. (1944). The idea of nationalism: A study in its origins and background. New York: Macmillan.

Kohn, Hans. (1946). Prophets and peoples: Studies in nineteenth century nationalism. New York: Macmillan.

Kohn, Hans. (1949). The twentieth century: A mid-way account of the western world. New York: Macmillan.

Kymlicka, Will. (1999). Misunderstanding nationalism. In R. Beiner(Ed.), Theorizing nationalism (pp. 131-140). Albany: State University of New York Press.

McCrone, David. (1998). The sociology of nationalism. London: Routledge.

Meincke, Friedrich. (1970). Cosmopolitanism and the national state (7th ed., Robert B. Kimber, Trans.). Princeton, NJ: Princeton University Press.

Nieguth, Tim. (1999). Beyond dichotomy: Concepts of the nation and the distribution of membership. Nations and Nationalism, 5, 155-173.

Nielsen, Kai. (1999). Cultural nationalism, neither ethnic nor civic. In R. Beiner (Ed.), Theorizing nationalism (pp. 119-130). Albany: State University of New York Press.

Renan, Emest. (1994). Qu'est-ce qu'une nation? [What is a nation?]. In J. Hutchinson \& A. D. Smith (Eds.), Nationalism (pp. 17-18). Oxford: Oxford University Press.

Schopflin, George. (1995). Nationalism and ethnicity in Europe, east and west. In C. A. Kupchan (Ed.), Nationalism and nationalities in the new Europe (pp. 37-65). Ithaca, NY: Cornell University Press.

Schopflin, George. (1996). Nationalism and ethnic minorities in post-communist Europe. In R. Caplan \& J. Feffer (Eds.), Europe's new nationalism (pp. 150-170). New York: Oxford University Press. 
Smith, Anthony D. (1986). The ethnic origins of nations. Oxford: Blackwell.

Smith, Anthony D. (1991). National identity. Reno: University of Nevada Press

Snyder, Jack. (1993). Nationalism and the crisis of the post-Soviet state. In M. E. Brown (Ed.)

Ethnic conflict and international security (pp. 79-101). Princeton, NJ: Princeton University Press.

Yack, Bernard. (1999). The myth of the civic nation. In R. Beiner (Ed.), Theorizing nationalism (pp. 103-118). Albany: State University of New York Press.

Stephen Shulman is an assistant professor in the Department of Political Science at Southern Illinois University. His research interests focus on nationalism and ethnic politics. He has an area specialization in the former Soviet Union, where he has conducted research and taught. His research appears in journals such as Europe-Asia Studies, Political Geography, Ethnic and Racial Studies, and International Studies Quarterly. 